\title{
Do Changes in Trading Hours Affect Return, Volatility and Liquidity? Evidence from Indonesia Stock Market
}

\author{
Naufal Wicaksono ${ }^{1, *}$, Intan Nurul Awwaliyah ${ }^{2}$, Marmono Singgih ${ }^{3}$ \\ ${ }^{1}$ Faculty of Economics and Business, University of Jember, Jember, Indonesia \\ ${ }^{2}$ Faculty of Economics and Business, University of Jember, Jember, Indonesia \\ ${ }^{3}$ Faculty of Economics and Business, University of Jember, Jember, Indonesia \\ *Corresponding author. Email: naufalw19@gmail.com
}

\begin{abstract}
The COVID-19 outbreak triggered various responses around the world, particularly on the Indonesia stock market. It can be seen that the Indonesia stock market is highly affected due to COVID-19 pandemic. This makes BEI has to take a policy so that the stock market is still attractive for investors. BEI has circulated a decree concerning changes in trading hours on exchange transactions. The objective of this research is to analyze the effect of changes in trading hours due to COVID-19 on Indonesia stock market toward abnormal return, volatility and liquidity of stocks. This research employs event study method with an observation period of 7 days before and 7 days after the changes in trading hours on Indonesia stock market. Data gathered in this research are the abnormal return, volatility and liquidity of LQ45 index from March 18 to April 8, 2020. The normality test conducted indicates that the data is not normally distributed. Therefore, the research hypothesis is tested using non-parametric test, namely the Wilcoxon Paired Sample Test. The results show that there are no significant differences in abnormal return and volatility before and after the changes in trading hours. However, there is significant difference in liquidity before and after the changes in trading hours.
\end{abstract}

Keywords: Changes in trading hours, abnormal return, volatility, liquidity, LQ45.

\section{INTRODUCTION}

The COVID-19 outbreak triggered various responses, particularly on the stock market around the world. In Indonesia, the government has declared the first case of COVID-19 infection in early March 2020. This infectious disease is not only affected health, but also the economy [1]. The economic condition due to COVID-19 was severely impacted and widespread in the financial sector. The weakening of the financial sector is followed by a weakening of the stock market around the world. Indonesia is no exception to this as well.

The weakening of the Indonesia stock market was indicated by a declining of the IDX Composite Index. On March 2, 2020, when the Indonesian government announced the first case of COVID-19 infection, the IDX Composite Index is closed lower by $1.67 \%$ [2]. Previously, the IDX Composite was in a bearish trend due to investors' negative sentiment on COVID-19.
The worst decline experienced by IDX Composite Index was on March 24, 2020, which was at the level of 3,937.6. This condition mostly caused by the downward trend of the stock prices from various sectors, including stocks comprising the LQ45 Index. To be noted, the LQ45 index is the main "stock driver" of the IDX Composite Index, thus the decline in the LQ45 Index impacted the IDX Composite Index. Among the LQ45 stocks that experienced the deepest correction during 2020 were PT Matahari Department Store Tbk (LPPF) and PT Perusahaan Gas Negara (PGAS) which decreased by $62.11 \%$ and $55.3 \%$ accordingly. In addition, the construction and property sector such as PT Wijaya Karya Tbk (WIKA) dan PT Indocement Tunggal Prakarsa Tbk (INTP) were also severely affected [3].

As can be seen in figure 1, the LQ45 index movement has the worst decrease during March and April 2020. The decrease of the LQ45 index and various sectors in Indonesia stock market cause 
Indonesia Stock Exchange (BEI) to make new adjustment regarding trading rules. In order to maintain market stability and support the implementation of work from home (WFH) rule to minimize the spread of COVID-19 in Indonesia, BEI has circulated a decree number Kep-00031/BEI/032020 concerning changes in trading hours on exchange transactions.

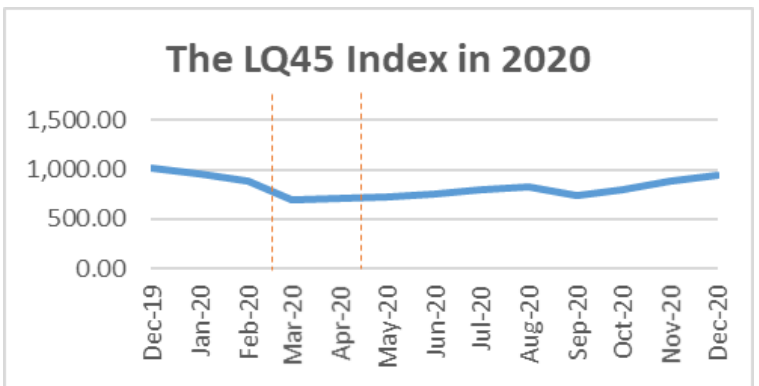

Figure 1. The LQ45 Index in 2020

The changes in trading hours may affect the investor behavior and market quality [4]. The IDX changes in trading hours since March 2020 has greatly affected the stock market and viewed as bad news for the investors [2]. The changes in trading hours may affect abnormal return since Indonesia can be classified as semi-strong market where there is a possibility of abnormal returns for investors [5]. Abnormal return is the difference of actual return and expected return. The existence of abnormal return also affected the LQ45 index indicated by the average difference of abnormal stock return in LQ45 during COVID-19 pandemic in Indonesia [6].

Instead of having impact toward abnormal return, changes in trading hours may affect volatility as well since risk viewed by investors is also shifting. A risky stock is a stock with high volatility [7]. Stock prices volatility occurs due to new information in the market [8]. The LQ45 index showed high volatility during the announcement of changes in trading hours. The level of high volatility of stock prices will cause investors to re-manage their traded assets [9]. A study on reductions in New York Stock Exchange (NYSE) trading hours showed that there is an effect on the intra-weekly return volatility distribution and trading volume [10]. The increasing trading volume is an indication of stock liquidity in the market.

The more liquid of stocks, the more return decreased. A liquid stock is considered to have less risk, while illiquid stock has a bigger risk [11]. The existence of changes in trading hours creates worry for investor that the liquidity will affect their return. Illiquidity is the form of risk. If the market is illiquid, the risk will increase because stock cannot be easily traded and it may cause by the changes in trading hours. Hence, based on the problems explained above, this research tries to analyze the effect of changes in trading hours on abnormal return, volatility and liquidity by using the event study method.

The changes of trading hours has been documented in previous studies such as Houston and Ryngaert (1992) that studied the reduced trading hours on New York Stock Exchange and showed that the reduced trading hours affect the weekly return volatility [10]. Fan and Lai (2006) studied the extension of trading hours on the Taiwanese stock market [4]. The results indicated that the trading hours extension have no impact on volatility while the bid-ask spread declined due to the trading hours extension on the Taiwanese stock market. Similarly, Chauhan and Agarwal (2010) studied the increased of trading hours on the Indian stock market and showed that the volatility decreased [14]. More recent study by Kusnandar and Bintari (2020) evaluated the impact of the changes in trading hours due to COVID-19 on abnormal returns on the Indonesia stock market. It showed that there were differences in abnormal returns before and after the changes in trading hours on the Indonesia Stock Exchange.

Extending the previous studies, this research is the first that documented the changes in trading hours of Indonesia stock market by employing three variables including abnormal return, volatility and liquidity. By using comprehensive approach, it is expected to see the impact of changes in trading hours on return, volatility and liquidity in Indonesia stock market as well as providing guidance for investors toward their future strategy.

\section{METHODOLOGY}

The objective of this research is to analyze whether there is a difference between abnormal return, volatility and liquidity before and after the changes in trading hours. This research uses event study method and test the hypotheses by employing historical data. The event study method is used to test the informational content based on the presence of announcements or information. If an announcement or information has information content then the market will react [12]. The impact of an event will be reflected in a company's asset prices [15]. Data used in this research is secondary data collected from the LQ45 stock prices (high, low, close and trading volume) and the number of outstanding stocks. The observation period was 14 days of trading activities which are 7 days prior and 7 days after the changes in trading hours enforced by BEI on 30 March 2020. The stocks that 
consistently form the LQ45 index during the research period are required. The method of collecting data is using purposive sampling method. There were 42 samples that met the criteria during the observation period. Variables tested in this study are abnormal return, volatility and liquidity of the LQ45 index. First, abnormal return is calculated by dividing the actual return by the expected return. The daily actual return is calculated by dividing the stock closing price today by stock closing price yesterday minus 1 . The expected return is then calculated by using the marketadjusted model. This model shows that the best stock returns estimator is market return.

Second, the daily volatility is calculated using the Parkinson volatility [13]. The Parkinson volatility is calculated by dividing daily stock high price by daily stock low price. Thirdly, the daily liquidity is calculated with the Amihud's Illiquidity [11]. The Amihud's Illiquidity is calculated by dividing daily stock return by the stock trading volume in Rupiah. This measure is suitable for the low frequency data such as daily data used in this study. The hypothesis tested is there is difference between abnormal return, volatility and liquidity before and after the changes in trading hours with a significance level of 5\% (0.05). If the Sig. (2-tailed) value is less than 0.05 , the hypothesis is accepted. If the Sig. (2-tailed) value is more than 0.05 , the hypothesis is rejected.

\section{RESULTS \& DISCUSSION}

Before testing hypothesis, the normality test is required as the main criteria in parametric statistic test. The results of normality test showed that all data are not normally distributed. Therefore, the hypothesis test used is the non-parametric test namely Wilcoxon Paired Sample Test.

Table 1 presents the statistical descriptive of abnormal return, volatility and liquidity. The mean of the abnormal return seems to be stagnant before the changes in trading hours applied. However, there is negative abnormal return during the day of the change in trading hours. This indicates that the investors are aware of information about the changes in trading hours. The abnormal return after the changes in trading hours appears to be stagnant. Even on 6 April 2020 $(\mathrm{t}+5)$, there is a positive abnormal return.

High volatility in stock market is evidence near the announcement of changes in trading hours. This is shown by the increase in trading activity around the days approaching the changes in trading hours $(\mathrm{t}-3, \mathrm{t}-$ $2, \mathrm{t}-1)$. Investors seem to be responsive on the information regarding stock market since Covid-19 news is covered in many medias. However, the volatilities after the changes in trading hours are seemed to be back to normal condition.

Table 1. Descriptive Statistic of Abnormal Return, Volatility and Liquidity

\begin{tabular}{c|cccc|rrrc|cccc}
\hline \multicolumn{5}{|c|}{ Abnormal Return } & \multicolumn{5}{c|}{ Volatility } & \multicolumn{4}{c}{ Liquidity } \\
\hline & Min & Max & Mean & SD & Min & Max & Mean & SD & Min & Max & Mean & SD \\
\hline $\mathrm{t}-7$ & -0.463 & 0.091 & -0.021 & 0.075 & 0.011 & 0.06 & 0.03 & 0.009 & $2.60 \mathrm{E}-14$ & $3.13 \mathrm{E}-11$ & $3.67 \mathrm{E}-12$ & $6.18 \mathrm{E}-12$ \\
\hline $\mathrm{t}-6$ & -0.004 & 0.166 & 0.006 & 0.033 & 0 & 0.072 & 0.018 & 0.015 & $5.70 \mathrm{E}-14$ & $2.62 \mathrm{E}-10$ & $2.32 \mathrm{E}-11$ & $5.25 \mathrm{E}-11$ \\
\hline $\mathrm{t}-5$ & -0.09 & 0.192 & 0.006 & 0.095 & 0.015 & 0.105 & 0.049 & 0.028 & $1.20 \mathrm{E}-14$ & $7.85 \mathrm{E}-12$ & $1.49 \mathrm{E}-12$ & $1.73 \mathrm{E}-12$ \\
\hline $\mathrm{t}-4$ & -0.004 & 0.107 & 0.006 & 0.025 & 0 & 0.067 & 0.025 & 0.014 & $6.70 \mathrm{E}-14$ & $4.81 \mathrm{E}-11$ & $5.66 \mathrm{E}-12$ & $8.32 \mathrm{E}-12$ \\
\hline $\mathrm{t}-3$ & -0.042 & 0.182 & 0.006 & 0.058 & 0.024 & 0.074 & 0.039 & 0.011 & 0 & $1.87 \mathrm{E}-11$ & $2.83 \mathrm{E}-12$ & $3.90 \mathrm{E}-12$ \\
\hline $\mathrm{t}-2$ & -0.199 & 0.099 & -0.033 & 0.063 & 0.032 & 0.102 & 0.06 & 0.015 & 0 & $8.46 \mathrm{E}-12$ & $1.83 \mathrm{E}-12$ & $1.95 \mathrm{E}-12$ \\
\hline $\mathrm{t}-1$ & -0.128 & 0.161 & 0.002 & 0.057 & 0.022 & 0.09 & 0.051 & 0.015 & $1.80 \mathrm{E}-14$ & $7.11 \mathrm{E}-12$ & $1.28 \mathrm{E}-12$ & $1.59 \mathrm{E}-12$ \\
\hline $\mathrm{t}$ & -0.03 & 0.109 & -0.009 & 0.035 & 0.013 & 0.06 & 0.026 & 0.008 & 0 & $1.64 \mathrm{E}-11$ & $3.72 \mathrm{E}-12$ & $4.16 \mathrm{E}-12$ \\
\hline $\mathrm{t}+1$ & -0.096 & 0.178 & 0.015 & 0.057 & 0.014 & 0.081 & 0.032 & 0.013 & 0 & $6.98 \mathrm{E}-12$ & $1.28 \mathrm{E}-12$ & $1.56 \mathrm{E}-12$ \\
\hline $\mathrm{t}+2$ & -0.05 & 0.049 & -0.004 & 0.024 & 0.015 & 0.07 & 0.033 & 0.012 & 0 & $6.14 \mathrm{E}-12$ & $1.03 \mathrm{E}-12$ & $1.43 \mathrm{E}-12$ \\
\hline $\mathrm{t}+3$ & -0.083 & 0.1 & 0.017 & 0.043 & 0.007 & 0.07 & 0.032 & 0.015 & $1.70 \mathrm{E}-14$ & $7.20 \mathrm{E}-12$ & $1.53 \mathrm{E}-12$ & $1.72 \mathrm{E}-12$ \\
\hline $\mathrm{t}+4$ & -0.081 & 0.184 & 0.013 & 0.052 & 0.011 & 0.063 & 0.025 & 0.013 & 0 & $5.29 \mathrm{E}-12$ & $1.09 \mathrm{E}-12$ & $1.27 \mathrm{E}-12$ \\
\hline $\mathrm{t}+5$ & -0.051 & 0.201 & 0.042 & 0.075 & 0.01 & 0.101 & 0.035 & 0.023 & 0 & $6.49 \mathrm{E}-12$ & $1.53 \mathrm{E}-12$ & $1.44 \mathrm{E}-12$ \\
\hline $\mathrm{t}+6$ & -0.052 & 0.256 & 0.021 & 0.062 & 0.018 & 0.091 & 0.041 & 0.015 & 0 & $2.83 \mathrm{E}-12$ & $5.50 \mathrm{E}-13$ & $7.08 \mathrm{E}-13$ \\
\hline $\mathrm{t}+7$ & -0.026 & 0.04 & -0.009 & 0.02 & 0.012 & 0.058 & 0.028 & 0.009 & $6.00 \mathrm{E}-15$ & $9.10 \mathrm{E}-12$ & $1.52 \mathrm{E}-12$ & $1.72 \mathrm{E}-12$ \\
\hline
\end{tabular}


In contrast, the stock liquidity prior and after the changes in trading hours are quite unlike. It is evidence that the mean of liquidity before the changes in trading hours is high. Meanwhile, after the changes in trading hours, the mean of liquidity is low or so be called as the lack of liquidity. In overall, there is an indicative that the changes in trading hours highly affect the liquidity of the LQ45 index.

The results of the Wilcoxon Paired Sample Test for each variable are presented in the table 2, 3 and 4 in the following. The conclusion is withdrawn if there are more than $50 \%$ of the observation falls into one category for instance there is difference or no difference in certain variable.

Table 2. Paired Sample Test on Abnormal Return

\begin{tabular}{ll}
\hline Conclusion & \multicolumn{1}{c}{ Pairs } \\
\hline & $t+1$ and $t-7, t+3$ and $t-7, t+4$ \\
There is & and $t-7, t+5$ and $t-7, t+6$ and $t-$ \\
Abnormal & and $t-6, t+5$ and $t-4, t+7$ and $t-$ \\
Return & $4, t+1$ and $t-2, t+2$ and $t-2, t+3$ \\
difference & and $t-2, t+4$ and $t-2, t+5$ and $t-$ \\
& $2, t+6$ and $t-2, t+7$ and $t-1, t+5$ \\
& and $t-1$ \\
\hline & $t+1$ and $t-6, t+2$ and $t-6, t+3$ \\
& and $t-6, t+4$ and $t-6, t+6$ and $t-$ \\
& $6, t+1$ and $t-5, t+2$ and $t-5, t+3$ \\
& and $t-5, t+4$ and $t-5, t+5$ and $t-$ \\
& $5, t+6$ and $t-5, t+7$ and $t-5, t+1$ \\
No Abnormal & and $t-4, t+2$ and $t-4, t+3$ and $t-$ \\
Return & $4, t+4$ and $t-4, t+6$ and $t-4, t+1$ \\
difference & and $t-3, t+2$ and $t-3, t+3$ and $t-$ \\
& $3, t+4$ and $t-3, t+5$ and $t-3, t+6$ \\
& and $t-3, t+7$ and $t-3, t+1$ and $t-$ \\
$1, t+2$ and $t-1, t+3$ and $t-1, t+4$ \\
and $t-1, t+6$ and $t-1, t+7$ and $t-$ \\
1
\end{tabular}

As can be seen in table 2, the result of the hypothesis test using the Wilcoxon Paired Sample test on abnormal return of the LQ45 index for 14 days prior and after the changes in trading hours show that there is no significant difference in abnormal return before and after the changes in trading hours since there are 31 pairs out of the total 49 pairs of days that have shown no difference in abnormal return.

For volatility as presented in table 3 , the result of the hypothesis test using the Wilcoxon Paired Sample Test on volatility of the LQ45 index for 14 days is rejected. It can be concluded that there is no significant difference in volatility before and after the changes in trading hours since there are 28 pairs out of the total 49 pairs of days that have shown no difference in volatility.
Table 3. Paired Sample Test on Volatility

\begin{tabular}{lll}
\hline Conclusion & \multicolumn{1}{c}{ Pairs } & N \\
\hline & $t+4$ and $t-7, t+6$ and $t-7, t+1$ \\
& and $t-6, t+2$ and $t-6, t+3$ and $t-$ \\
There is & $6, t+4$ and $t-6, t+5$ and $t-6, t+6$ & \\
volatility & and $t-6, t+7$ and $t-6, t+1$ and $t-$ \\
difference & $5, t+2$ and $t-5, t+3$ and $t-5, t+4$ & 21 \\
& and $t-5, t+5$ and $t-5, t+7$ and $t-$ \\
& $5, t+1$ and $t-4, t+2$ and $t-4, t+5$ \\
& and $t-4, t+6$ and $t-4, t+5$ and $t-$ \\
& $3, t+6$ and $t-3$ \\
\hline & $t+1$ and $t-7, t+2$ and $t-7, t+3$ \\
& and $t-7, t+5$ and $t-7, t+7$ and $t-$ \\
& $7, t+6$ and $t-5, t+3$ and $t-4, t+4$ \\
& and $t-4, t+7$ and $t-4, t+1$ and $t-$ \\
& $3, t+2$ and $t-3, t+3$ and $t-3, t+4$ \\
No volatility & and $t-3, t+7$ and $t-3, t+1$ and $t-$ \\
difference & $2, t+2$ and $t-2, t+3$ and $t-2, t+4$ \\
& and $t-2, t+5$ and $t-2, t+6$ and $t-$ \\
& $2, t+7$ and $t-2, t+1$ and $t-1, t+2$ \\
& and $t-1, t+3$ and $t-1, t+4$ and $t-$ \\
& $1, t+5$ and $t-1, t+6$ and $t-1, t+7$ \\
& and $t-1$
\end{tabular}

Table 4. Paired Sample Test on Liquidity

\begin{tabular}{ll}
\hline Conclusion & \multicolumn{1}{c}{ Pairs } \\
\hline & $t+1$ and $t-7, t+2$ and $t-7, t+3$ \\
& and $t-7, t+4$ and $t-7, t+5$ and $t$ - \\
& $7, t+6$ and $t-7, t+7$ and $t-7, t+1$ \\
& and $t-6, t+2$ and $t-6, t+3$ and $t-$ \\
& $6, t+4$ and $t-6, t+5$ and $t-6, t+6$ \\
There is & and $t-6, t+7$ and $t-6, t+6$ and $t-$ \\
liquidity & $5, t+1$ and $t-4, t+2$ and $t-4, t+3$ \\
difference & and $t-4, t+4$ and $t-4, t+5$ and $t-$ \\
& $4, t+6$ and $t-4, t+7$ and $t-4, t+1$ \\
& and $t-3, t+2$ and $t-3, t+4$ and $t-$ \\
& $3, t+6$ and $t-3, t+7$ and $t-3, t+1$ \\
& and $t-2, t+2$ and $t-2, t+4$ and $t-$ \\
& $2, t+6$ and $t-2, t+5$ and $t-1, t+6$ \\
& and $t-1$ \\
\hline & $t+1$ and $t-5, t+2$ and $t-5, t+3$ \\
& and $t-5, t+4$ and $t-5, t+5$ and $t-$ \\
& $5, t+7$ and $t-5, t+3$ and $t-3, t+5$ \\
No liquidity & and $t-3, t+3$ and $t-2, t+5$ and $t-$ \\
difference & $2, t+7$ and $t-2, t+1$ and $t-1, t+2$ \\
& and $t-1, t+3$ and $t-1, t+4$ and $t-$ \\
& $1, t+7$ and $t-1$
\end{tabular}

As can be seen in table 4, the hypothesis test using the Wilcoxon Paired Sample Test on liquidity of the LQ45 index cannot be rejected. It can be observed that during 14 days prior and after the changes in trading hours, there is significant difference in stock liquidity. There are 33 pairs out of the total 49 pairs of days that have shown significant difference in liquidity. 
This results in particular, supports [16] study which showed that the changes in trading hours have no impact on volatility. However, the bid-ask spread as a measure of liquidity is affected due to the changes in trading hours [4].

\section{CONCLUSION}

Based on the results above, it can be concluded that there are no significant differences in both abnormal return and volatility before and after the changes in trading hours in Indonesia stock market. Meanwhile, there is significant difference in liquidity before and after the changes in trading hours. The main implication of this study is there are market reactions due to changes in trading hours. Changes in trading hours are considered as a "bad sign" by investors. Additionally, the impact is heightened by the COVID19 pandemic that more vicious and spread widely as covered in news. The market reaction is shown by significant difference of stock liquidity before and after the changes in trading hours. The lack of liquidity will result the increase of investors' risk in their assets. Therefore, changes in trading hours may considered as an important information content that can explained stock market movements. For investors, this research can be used as a reference to re-manage their assets during the changes in trading hours due to COVID-19. However, this study is limited only to see the impact of changes in trading hours in return, volatility and liquidity by employing low frequency data. For unexplored issues in this study, it is suggested in further research, to employ other volatility and liquidity measures such as Garman-Klass volatility estimator and bid-ask spread as well as employing high frequency data to gain more understanding towards the impact. Widening the coverage by comparing with other stock markets such as Asia Pacific region will be noteworthy.

\section{REFERENCES}

[1] H. Liu, A. Manzoor, C. Wang, et al, "The COVID19 Outbreak and Affected Countries Stock Markets Response," International Journal of Environmental Research and Public Health, doi: 10.3390/ijerph17082800

[2] D. L. Kusnandar and V. I. Bintari, "Perbandingan Abnormal Return Saham Sebelum dan Sesudah Perubahan Waktu Perdagangan Selama Pandemi Covid-19," Jurnal Pasar Modal dan Bisnis, Vol 2, No.2, Agustus 2020, pp. 195-202. doi: 10.37194/jpmb.v2i2.49
[3] CNBC Indonesia, Derita 9 Saham LQ45, Hancur Lebur karena Ambles 40\% Lebih [Internet], 2020, Available from: https://www.cnbcindonesia.com/market/2020100 7153959-17-192553/derita-9-saham-lq45-hancurlebur-karena-ambles-40-lebih

[4] Y. Fana and H. Lai, "The Intraday Effect and The Extension of Trading Hours for Taiwanese Securities," International Review of Financial Analysis, vol. 15, pp. 328 - 347, 2006, doi: 10.1016/j.irfa.2006.02.005

[5] P. R. Romdiani, and G. I. Kurniawan, "Differences Abnormal Return and Cumulative Abnormal Return Financial Sector Issuers for the Previous Period and Time of the Covid-19 Pandemic," Financial Management Studies, vol. 1, no. 2, pp. 01-11, 2021, doi: 10.24036/jkmb.xxxxxxxx

[6] I. K. A. T. Sukadarma, N. W. K. Dewi, and I. K. Pranata, "The Analysis of Abnormal Stock Returns in LQ-45 Index During Covid-19 Pandemic," Journal of Applied Sciences in Accounting, Finance, and Tax, vol. 4, no. 1, 2021, doi: 10.31940/jasafint.v4i1.2413

[7] K. O. Novian, I. N. Awwaliyah, and H. Paramu, "Price Manipulation During the Indonesian Presidential Election of 2019: Does it Matter Toward Return, Volatility and Liquidity?," International Conference on Global Innovation and Trends in Economy, vol. 3, no. 1, 2020.

[8] B. Sutrisno, "Hubungan Volatilitas dan Volume Perdagangan di Bursa Efek Indonesia," Jurnal Bisnis dan Manajemen, vol. 7, no. 1, April 2017. doi: 10.15408/ess.v7i1.3894

[9] L. Santioso and Y. G. Angesti, "Faktor-Faktor Yang Mempengaruhi Volatilitas Harga Saham Perusahaan Manufaktur," Jurnal Ekonomi, vol. XXIV, No. 01, pp. 46-64, March 2019, doi: 10.24912/je.v24i1.450

[10] J. F. Houston, M. D. Ryngaert, The Links Between Trading Time and Market Volatility, in: The Journal of Financial Research Vol. XV, No. 2. DOI: https://doi.org/10.1111/j.14756803.1992.tb00790.x

[11] Y. Amihud, "Illiquidity and Stock Returns: Cross-Section and Time-Series Effects," Journal of Financial Markets, vol. 5, pp. 31-56, 2002, doi: 10.1016/S1386-4181(01)00024-6

[12] Andreas, T. A. Gumanti, U. Nurjannah, and I. N. Awwaliyah, "The Effect of Announcement as the Host of XVIII Asian Games on the Indonesian 
Stock Market," Investment Management and Financial Innovations, 2020, doi: 10.21511/imfi.17(1).2020.10

[13] P. Molnar, "Property of Range-Based Volatility Estimators," International Review of Financial Analysis, vol. 23, pp. 20-29, 2012, doi: 10.106/j.irfa.2011.06.012

[14] A. K. Chauhan and K. Agarwal, "Increased Trading Hours and its Post-impact on Market Efficiency: Empirical Evidence from the Indian," Stock Market, 2010, doi: 10.2139/ssrn.1670688

[15] A. P. Dewantara, I. N. Awwaliyah, and M. Singgih, "The Impact of Constitutional Court Ruled on the 2019 Presidential Election Toward Indonesian Stock Market," International Conference on Global Innovation and Trends in Economy. vol. 3, no. 1, 2020.

[16] J. Fan, and N. Lai, "The Intraday Effect and The Extension of Trading Hours for Taiwanese Securities," International Review of Financial Analysis, vol. 15, pp. 328- 347, 2006. 